Aneta BĄK-SZOŁUCHA ${ }^{1}$

DOI: https://doi.org/10.53052/9788366249875.07

\title{
SERWIS YOUTUBE I SPOSÓB JEGO UŻYTKOWANIA PRZEZ PUBLICZNE UCZELNIE TECHNICZNE W POLSCE
}

Streszczenie: W artykule przedstawiono wyniki badań nad aktywnością uczelni technicznych wyższych w serwisie społecznościowym YouTube. Badania wykazały, że uczelnie techniczne na podobnym poziomie jak uniwersytety, korzystały z opisywanego serwisu. W 2017 roku aż 15 uczelni technicznych na 18 korzystało z YouTube.

Słowa kluczowe: komunikacja, social media, nowe technologie, YouTube, uczelnie wyższe

\section{YOUTUBE IN USE BY PUBLIC TECHNICAL UNIVERSITIES IN POLAND}

Summary: In the article the results of the research on the activity of technical universities in YouTube were presented. The conducted research confirmed that technical universities availed themselves of YouTube service just as much as universities. In 2017 as many as 15 out of 18 engineering institutes used YouTube.

Keywords: communications, social media, new technology, YouTube, universities

\section{Wprowadzenie - w świecie YouTuba}

Serwisy społecznościowe takie jak Facebook, YouTube czy Instagram z całą pewnością $\mathrm{w}$ przeciągu ostatnich lat stały się znaczącym elementem nowoczesnej komunikacji, o czym może świadczyć fakt, że jego twórcy co jakiś czas (czasami co tydzień, co miesiąc, rok) wprowadzają do ich funkcjonowania coraz to nowsze rozwiązania czy też nowe funkcje mające ulepszyć ich funkcjonalność.

Liczba użytkowników social mediów w ostatnim roku wzrosła o prawie 10 procent i obecnie mówi się o 4,5 miliarda użytkowników mediów społecznościowych. Ponad 400 milionów użytkowników zaczęło korzystać z platform społecznościowych w ciągu ostatnich 12 miesięcy [1]. Fenomen serwisów społecznościowych polega na tym, iż każdy jego użytkownik sam tworzy sieć własnych powiązań, sam decyduje o sile powstających więzi, podtrzymywaniu czy zaniechaniu kontaktów i ich rozległości.

1 dr, Akademia Techniczno-Humanistyczna w Bielsku-Białej, Wydział Zarządzania i Transportu, Katedra Nauk Ekonomicznych i Społecznych, abak@ath.bielsko.pl 
YouTube to jeden z przykładów social media, który ,umożliwia miliardom ludzi odkrywanie, oglądanie i udostępnianie oryginalnych filmów. (...) oferuje użytkownikom na całym świecie forum, dzięki któremu mogą się spotykać, komunikować i inspirować, oraz platformę dystrybucji przeznaczoną dla autorów oryginalnych prac, a także reklamodawców dowolnej wielkości" [2]. YouTube powstał w lutym 2005, twórcami serwisu byli Chad Hurley, Steve Chen oraz Jawed Karim. YouTube to serwis, na którym użytkownicy mogą się dzielić z innymi materiałami wideo. Operując obrazem jako najstarszą formą ludzkiej komunikacji YouTube doskonale się sprawdza we współczesnym świecie, bowiem ludzie coraz częściej zamiast czytać wolą patrzeć i przeglądać. Kiedy 23 kwietnia 2005 w serwisie YouTube pojawił się pierwszy 18 sekundowy film nagrany przez Yakova Lipitsky'ego pokazującego jego kolegę Jaweda $w$ zoo na tle słoni nikt nie przypuszczał, że będzie to początek filmowo-internetowej rewolucji [3].

YouTube to serwis społecznościowy, który przez ostatnie 16 lat zmienił rynek wideo w sieci, ale również zdefiniował go na nowo i zaczął wyznaczać trendy na rynku medialnym. Oczywiście stało się tak nie tylko za sprawą samego serwisu, ale również rewolucji technologicznej, która przyczyniła się do tego, że nagrywanie i edycja materiałów wideo w Internecie poprzez social media jest powszechna, bowiem dostępna dla każdego (każdego posiadacza telefonu komórkowego) i przede wszystkim tania. Jak pisze Paul Levinson ,(...) najbardziej niespodziewany i długofalowy wpływ, jaki wywarł YouTube na ewolucje mediów, związany jest z klipami wideo realizowanymi przez amatorów, przez ludzi, którzy nie są profesjonalnymi producentami telewizyjnymi"[4].

Funkcjonujący od 16 lat serwis YouTube jest obecnie jedną z najbardziej użytkowanych platform społecznościowych za raz po Facebooku. W 2020 roku serwis odnotował 2 miliardy czynnych użytkowników [1]. Bez wątpienia serwis ten można zakwalifikować do najważniejszego nadawcy przekazów audiowizualnych, który ze względu na coraz to nowe możliwości (np. wprowadzona w 2010 roku darmowa możliwość transmisji na żywo (tzw. streaming), czy też decyzja z 2014 roku dotycząca zwiększenia liczby wyświetleń jednego wideo do maksymalnej granicy licznika do 64-bitowej liczby całkowitej wynoszącej grubo ponad 9 trylionów [3] podbiera stacjom telewizyjnym i nie tylko reklamowych żywicieli. Coraz większą atrakcyjność YouTuba potwierdza również fakt, iż w Polsce w ciągu ostatnich kilku lat systematycznie zwiększa się zasięg analizowanego serwisu. „O ile w styczniu 2012 r. zasięg wśród internautów PC był na poziomie blisko 69 proc., o tyle w styczniu 2017 roku było to już 79 proc. Obecnie sumarycznie z serwisu korzysta aż 20 mln użytkowników. Z mobilnej aplikacji serwisu korzysta blisko 13,6 mln użytkowników" [5]. Jak pokazują badania grupy Gemius PBI z roku na rok polska liczba użytkowników YouTuba rośnie: w 2014 roku z serwisu korzystało 16,2 mln osób, w styczniu 2017 roku $20 \mathrm{mln}$ osób. Ponadto warto dodać, iż do grupy najpopularniejszych użytkowników YouTube w Polsce należą osoby w wieku 15-24 lat i 25-35 lat [6], co potwierdza zainteresowanie opisywanym serwisem publicznych uczelni w Polsce, w tym uczelni technicznych.

Celem niniejszego artykułu jest prezentacja wyników analizy serwisu YouTube, wykorzystywanego przez polskie uczelnie publiczne, również przez uczelnie techniczne jako jednego $\mathrm{z}$ wielu narzędzi rozbudowanej i interaktywnej komunikacji $\mathrm{z}$ otoczeniem. 


\section{O przedmiocie badań i metodzie}

W badaniu zostało uwzględnionych 59 polskich uczelni publicznych, które w dniu 12 grudnia 2017 roku znajdowały się w spisie Ministerstwa Nauki i Szkolnictwa Wyższego. Badaniem zostało objętych osiemnaście uniwersytetów, osiemnaście uczelni technicznych, po pięć uczelni ekonomicznych i uczelni pedagogicznych, sześć uczelni rolniczych/przyrodniczych, a także uczelni wychowania fizycznego i jedna uczelnia teologiczna. Z 59 uczelni do właściwej analizy zaakcentowanej w tytule artykułu zostało wybranych 15 jednostek akademickich, uczelnie techniczne, które w dniu zbierania danych posiadały oficjalny kanał/konto w serwisie YouTube (Tab.1). Swojego profilu na YouTube w 2017 roku nie posiadały trzy uczelnie techniczne: Politechnika Białostocka, Politechnika Lubelska i Politechnika Koszalińska.

Tabela 1. Lista profili analizowanych uczelni technicznych $w$ serwisie YouTube dane na rok 2017 (opracowanie wtasne)

\begin{tabular}{|c|c|c|}
\hline $\mathrm{Lp}$ & Uczelnia & $\begin{array}{c}\text { Konto na YouTube - } 2017 \\
\text { (liczba wyświetleń na profilu YouTube } \\
\text { stan na 31.12.2107) }\end{array}$ \\
\hline 1 & Politechnika Wrocławska & 3303235 \\
\hline 2 & $\begin{array}{l}\text { Akademia Górniczo-Hutnicza im. } \\
\text { Stanisława Staszica w Krakowie } \\
\end{array}$ & 631400 \\
\hline 3 & Politechnika Opolska & 340616 \\
\hline 4 & Politechnika Gdańska & 224846 \\
\hline 5 & Politechnika Śląska (Gliwice) & 177309 \\
\hline 6 & Politechnika Świętokrzyska w Kielcach & 93268 \\
\hline 7 & $\begin{array}{l}\text { Politechnika Krakowska im. Tadeusza } \\
\text { Kościuszki }\end{array}$ & 63720 \\
\hline 8 & $\begin{array}{l}\text { Politechnika Rzeszowska im. Ignacego } \\
\text { Łukasiewicza }\end{array}$ & 62192 \\
\hline 9 & Politechnika Warszawska & 61085 \\
\hline 10 & Politechnika Łódzka & 51421 \\
\hline 11 & Politechnika Częstochowska & 41379 \\
\hline 12 & $\begin{array}{l}\text { Uniwersytet Technologiczno- } \\
\text { Humanistyczny im. Kazimierza } \\
\text { Pułaskiego w Radomiu }\end{array}$ & 34389 \\
\hline 13 & $\begin{array}{l}\text { Akademia Techniczno-Humanistyczna } \\
\text { w Bielsku-Białej }\end{array}$ & 16967 \\
\hline 14 & Politechnika Poznańska & 12573 \\
\hline 15 & $\begin{array}{l}\text { Zachodniopomorski Uniwersytet } \\
\text { Technologiczny w Szczecinie }\end{array}$ & brak danych \\
\hline
\end{tabular}


Prezentowany artykuł ma na celu udzielenie odpowiedzi na następujące szczegółowe pytania badawcze:

Jaka liczba publicznych uczelni wyższych, w tym technicznych, korzystała w 2017 roku z serwisu YouTube oraz jaka była średnia liczba wyświetleń i subskrypcji dla tego kanału?

Czy rodzaj uczelni miał wpływ na użytkowanie kanału YouTube?

Jak wyglądała liczba publikacji materiałów audiowizualnych na YouTubie, w zależności od rodzaju uczelni akademickiej, a także od czasu założenia przez uczelnię oficjalnego konta na serwisie?

Jak wyglądała liczba subskrypcji kanału uczelni oraz liczba wyświetleń zamieszczonych tam materiałów, w zależności od rodzaju uczelni?

Jakiego rodzaju posty/materiały audiowizualne były najbardziej popularne na oficjalnym kanale YouTube badanych uczelni?

Aby odpowiedzieć na wyżej postawione pytania badawcze przeprowadzono następujące czynności badawcze.

W przeprowadzonej analizie celem było pokazanie w jaki sposób uczelnie techniczne korzystają z serwisu YouTube. Na pierwszym etapie badań odwiedzono z poziomu wykazu znajdującego się na stronie Ministerstwa Nauki i Szkolnictwa Wyższego główną stronę internetową każdej uczelni akademickiej. Na 59 przypadków akademickich uczelni publicznych jedynie w 3 przypadkach nie udało się odwiedzić głównej strony uczelni ze strony Ministerstwa zawierającego wykaz wszystkich uczelni publicznych. Kolejną czynnością na tym etapie badań było wyszukanie na głównej stronie uczelni linku bądź loga bądź ikony przekierowującej do serwisu YouTube. Znalezienie wskazanych elementów serwisu społecznościowego na stronach akademickich uczelni publicznych, w tym technicznych, nie przysparzało większych trudności, bowiem w większości przypadków znajdywały się one na górze (nagłówku) lub na dole (stopce) głównej strony uczelni bądź w lewym lub prawym pionowym pasku nawigacyjnym.

Drugim właściwym etapem naukowych eksploracji była ogólna analiza zawartości oficjalnych kont 53 uczelni na YouTubie, w tym 16 technicznych. Na tym etapie badań analizie ilościowej poddano podstawowe informacje znajdujące się na stronie głównej profilu badanych uczelni (były to tzw. karty serwisu: karta główna, wideo, playlisty, kanały, dyskusja i informacje). A zatem zinwentaryzowano wszystko to, co się znajdowało na karcie głównej analizowanego social media, liczbę wyświetleń, liczbę subskrypcji kanału uczelni, a także tematykę, liczbę oraz częstotliwość udostępnianych filmów. W dalszej kolejności uwaga została skierowana na to, czy badane uczelnie posiadały na oficjalnym koncie własne „Playlisty” oraz czy w ogóle zamieszczały na oficjalnym profilu jakiekolwiek informacje w karcie „Informacje”. Jeśli uczelnie to robiły, to jakiego rodzaju były to informacje. Na trzecim etapie badań analizowano udostępnione przez uczelnie materiały audiowizualne pod kątem ich popularności wśród osób oglądających.

Dane dotyczące informacji czy dana uczelnia posiada oficjalny profil na serwisie YouTube zostały zebrane w dniu 12 grudnia 2017 roku, natomiast analiza tego co się znajdowało się na oficjalnych kanałach uczelnianych na YouTubie była przeprowadzona w dniach 13 - 20 grudnia 2017 roku. 


\section{Uczelnie techniczne na YouTubie}

Posiadanie konta na kanale YouTube stwierdzono w przypadku 48 na 59 publicznych uczelni wyższych, dla uczelni technicznych było to 15 na 18 jednostek akademickich. Praktycznie dla każdego rodzaju uczelni odnotowano aktywność w serwisie YouTube, za wyjątkiem uczelni teologicznej - Chrześcijańskiej Akademii Teologicznej w Warszawie. Uczelnia ta ani w 2017, ani w 2020 roku nie posiadała swojego profilu na YouTubie (Tab.2).

Tabela 2. Liczba uczelni posiadająca swój profil na YouTubie w 2017 roku z uwzględnieniem rodzaju uczelni (opracowanie własne)

\begin{tabular}{|l|c|c|c|}
\hline \multicolumn{1}{|c|}{ Rodzaj uczelni } & $\begin{array}{c}\text { Ogólna liczba } \\
\text { uczelni }\end{array}$ & $\begin{array}{c}\text { Liczba uczelni } \\
\text { posiadająca profil na } \\
\text { YouTubie 2017 }\end{array}$ & $\begin{array}{c}\text { Liczba uczelni } \\
\text { posiadająca profil na } \\
\text { YouTubie 2020 }\end{array}$ \\
\hline Uniwersytety & 18 & 16 & 18 \\
\hline Uczelnie techniczne & 18 & 15 & 16 \\
\hline Uczelnie ekonomiczne & 5 & 4 & 5 \\
\hline Uczelnie pedagogiczne & 5 & 4 & 6 \\
\hline $\begin{array}{l}\text { Uczelnie rolnicze/ } \\
\text { przyrodnicze }\end{array}$ & 6 & 5 & 4 \\
\hline $\begin{array}{l}\text { Uczelnie wychowania } \\
\text { fizycznego }\end{array}$ & 6 & 4 & 0 \\
\hline Uczelnie teologiczne & 1 & 0 & 53 \\
\hline Razem & 59 & 48 & 5 \\
\hline
\end{tabular}

Choć serwis YouTube funkcjonuje na rynku medialnym od 2005 roku, badane uczelnie najwcześniej zaczęły go używać w 2008 roku. Pierwszymi uczelniami, które w tym roku założyły oficjalne profile na YouTubie była uczelnia techniczna Politechnika Wrocławska i uniwersytet - Uniwersytet Ekonomiczny w Poznaniu. W 2009 i 2010 roku, w sumie, oficjalny profil na YouTubie posiadało już szesnaście kolejnych uczelni. W następnych dwóch latach przybyło osiem uczelnianych profili. Najwięcej uczelni założyło swój kanał na YouTubie w 2013 roku, bo aż jedenaście (działania takie podjęło sześć uniwersytetów, cztery uczelnie techniczne oraz jedna uczelnia rolnicza/przyrodnicza). Rok 2014 i 2015 to wzrost profili o kolejne cztery uczelnie. Niestety w 2016 i 2017 roku żadna uczelnia nie zdecydowała się i tym samym nie założyła konta na YouTubie. Niestety w przypadku siedmiu badanych uczelni data założenia oficjalnego profilu uczelni na YouTubie nie była podana, badane jednostki nie zmieściły takiej informacji na swoim profilu.

Istotną kwestią dotyczącą każdego kanału na YouTubie jest liczba subskrypcji oraz aktualna liczba wyświetleń (Tab.3). Subskrypcja jest to informacja o tym jaka liczba użytkowników, subskrybuje dany kanał w YouTube, jest to po prostu wartość, która określa, ile osób faktycznie obserwuje dany kanał. Z zebranych w 2017 roku danych wynikało, że największą liczbę osób obserwujących dany kanał uczelni posiada uczelnia techniczna Politechnika Wrocławska (10 467 osób). Średnia liczba subskrypcji (obserwacji danego kanału) dla wszystkich przebadanych uczelni wynosiła 742,5. Z kolei, jeśli chodzi o średnią wartość subskrypcji w odniesieniu do rodzaju uczelni to największą liczbę obserwujących miały uniwersytety tj. 1026,3 
osób, na drugim miejscu znalazły się uczelnie techniczne (1 007,8osób) i na trzecim uczelnie ekonomiczne (504,2 osób).

Tabela 3. Liczba subskrypcji na YouTubie dla uczelni technicznych - dane dla 2017 roku (opracowanie wtasne)

\begin{tabular}{|l|c|}
\hline \multicolumn{1}{|c|}{ Uczelnia } & Liczba subskrypcji 2017 \\
\hline Politechnika Wrocławska & 10467 \\
\hline $\begin{array}{l}\text { Akademia Górniczo-Hutnicza im. Stanisława Staszica w } \\
\text { Krakowie }\end{array}$ & 1396 \\
\hline Politechnika Gdańska & 996 \\
\hline Politechnika Śląska (Gliwice) & 488 \\
\hline Politechnika Warszawska & 355 \\
\hline Politechnika Opolska & 330 \\
\hline Politechnika Świętokrzyska w Kielcach & 210 \\
\hline Politechnika Łódzka & 207 \\
\hline Politechnika Rzeszowska im. Ignacego Łukasiewicza & 181 \\
\hline Politechnika Krakowska im. Tadeusza Kościuszki & 163 \\
\hline Politechnika Poznańska & 98 \\
\hline $\begin{array}{l}\text { Zachodniopomorski Uniwersytet Technologiczny w } \\
\text { Szczecinie }\end{array}$ & 91 \\
\hline Politechnika Częstochowska & 65 \\
\hline $\begin{array}{l}\text { Akademia Techniczno-Humanistyczna w Bielsku - } \\
\text { Białej }\end{array}$ & 47 \\
\hline $\begin{array}{l}\text { Uniwersytet Technologiczno-Humanistyczny im. } \\
\text { Kazimierza Pułaskiego w Radomiu }\end{array}$ & 23 \\
\hline
\end{tabular}

Jeśli chodzi o wygląd i zawartość karty głównej kanału YouTube badanych uczelni, która wyświetlała się po przekierowaniu z głównej strony internetowej jednostki akademickiej, aż 62,5\% uczelni zgodnie z założeniami serwisu taką kartę posiadało. To znaczy, że widzowie odwiedzający kanał uczelni na YouTubie, w pierwszym momencie odwiedzenia kanału mieli możliwość obejrzenia wskazanego przez uczelnie bieżącego strumienia jej aktywności. W 73\% upublicznione w ten sposób materiały, z jakimi spotykali się widzowie wyświetlający po raz pierwszy profil YouTube badanej uczelni, były promocyjnymi materiałami wideo uczelni. Pozostałe 27\% wideo, wyświetlające się na karcie głównej profilu, dotyczyło wydarzeń bieżących z życia uczelni. Niestety nie zawsze w momencie zbierania danych informacje były aktualne i na czasie.

Drugą w kolejności kartą w serwisie YouTube jest karta wideo, na której znajdują się wszystkie filmy dostępne publicznie dla subskrybentów lub wszystkie filmy publicznie polubione przez właściciela kanału. Zawartość listy można sortować według dwóch kategorii: najbardziej popularnych filmów lub daty dodania materiału wideo (od najstarszego do najnowszego). Bezapelacyjnym liderem wśród uczelni technicznych (Tab.4) jeśli chodzi o liczbę udostępnianych na oficjalnym kanale uczelni filmów była Politechnika Opolska z liczbą 431 filmów, na drugim miejscu znalazła się Politechnika Wrocławska z liczbą 278 filmów i na trzecim miejscu Politechnika Gdańska 190 filmów. Najmniej udostępnionych filmów miał Zachodniopomorski Uniwersytet Technologiczny w Szczecinie tylko 16 filmów. 
Tabela 4. Liczba udostępnionych filmów na oficjalnych profilach uczelni na YouTubie (opracowanie wtasne)

\begin{tabular}{|l|c|c|}
\hline \multicolumn{1}{|c|}{ Uczelnia } & $\begin{array}{c}\text { Data założenia } \\
\text { profilu }\end{array}$ & Liczba filmów \\
\hline Politechnika Opolska & 2012 & 431 \\
\hline Politechnika Wrocławska & 2008 & 278 \\
\hline Politechnika Gdańska & 2009 & 190 \\
\hline Politechnika Świętokrzyska w Kielcach & 2014 & 186 \\
\hline Politechnika Śląska (Gliwice) & 2009 & 174 \\
\hline $\begin{array}{l}\text { Akademia Górniczo-Hutnicza im. Stanisława Staszica w } \\
\text { Krakowie }\end{array}$ & 2009 & 144 \\
\hline Politechnika Częstochowska & 2011 & 121 \\
\hline Politechnika Krakowska im. Tadeusza Kościuszki & 2013 & 84 \\
\hline Politechnika Łódzka & 2013 & 64 \\
\hline $\begin{array}{l}\text { Akademia Techniczno-Humanistyczna wielsku - } \\
\text { Białej }\end{array}$ & 2010 & 46 \\
\hline Politechnika Warszawska & 2013 & 43 \\
\hline Politechnika Poznańska & 2015 & 32 \\
\hline Politechnika Rzeszowska im. Ignacego Łukasiewicza & 2013 & 30 \\
\hline $\begin{array}{l}\text { Uniwersytet Technologiczno-Humanistyczny im. } \\
\text { Kazimierza Pułaskiego w Radomiu }\end{array}$ & 2011 & 16 \\
\hline $\begin{array}{l}\text { Zachodniopomorski Uniwersytet Technologiczny } \\
\text { w Szczecinie }\end{array}$ & - & 80 \\
\hline
\end{tabular}

Badane uczelnie średnio w miesiącu zamieszczały 2,20833 filmów, natomiast średnia liczba filmów opublikowanych w przeciągu jednego tygodnia dla ogółu przebadanych uczelni wynosiła 0,75000 filmu.

Na potrzeby analizy zamieszczonych filmów wideo na oficjalnym profilu uczelni na YouTube wprowadzono dwie kategorie: pierwsza „najpopularniejsze” i druga wskazująca na starość czy też nowość opublikowanego materiału. W artykule przedstawiona zostanie jedynie lista najbardziej popularnych filmów ze względu na ich ogólny temat. Używając filtru wideo „najpopularniejsze” można wyróżnić te filmy, które w porównaniu z innymi materiałami audiowizualnymi są najbardziej popularne, czyli zostały wyświetlone najwięcej razy. Kategorię 'najpopularniejszy film' zamieszczony na kanale YouTube uczelni przeanalizowano dla grupy 41 uczelni (Tab.5).

Zdecydowanie na pierwszym miejscu znalazły się wszystkie filmy, które dotyczyły szeroko rozumianej promocji uczelni (w tym określonych kierunków, nowych miejsc, czy całej uczelni) - było to 46,3\% wszystkich najpopularniejszych filmów znajdujących się na miejscu pierwszym we wszystkich przebadanych profilach uczelni. W dalszej kolejności na pierwszym miejscu znalazły się filmy dotyczące propagowania, na różny sposób, wiedzy zarówno tej akademickiej i nie tylko - 34,1\% filmów oraz materiały z bieżącej działalności uczelni - 14,6\%. Na miejscu drugim na wszystkich analizowanych profilach ponownie w czołówce najpopularniejszych filmów znalazły się te dotyczące akcji promocyjnych danej uczelni - 65,9\% wszystkich filmów, dalej materiały propagujące wiedzę - 24,4\% oraz aktualności $7,3 \%$. Na trzecim miejscu wszystkich najpopularniejszych wideo znalazły się w podobnej kolejności takie materiały jak: spoty reklamowe i promocyjne uczelni 
$61 \%$, materiały związane z upowszechnianiem wiedzy $24,4 \%$ oraz informacje bieżące $12,2 \%$ wyświetlonych na profilu uczelni filmów.

Tabela 5. Najpopularniejsze filmy na profilach uczelni ze względu na temat (opracowanie wtasne)

\begin{tabular}{|l|c|c|c|}
\hline \multicolumn{1}{|c|}{ Tematyka najpopularniejszych filmów } & $\begin{array}{c}\text { Miejsce } \\
\text { pierwsze }\end{array}$ & Miejsce drugie & $\begin{array}{c}\text { Miejsce } \\
\text { trzecie }\end{array}$ \\
\hline Materiały promujące uczelnię & 19 & 27 & 25 \\
Materiały propagujące wiedzę (np. wykłady, & $46,3 \%$ & $65,9 \%$ & $61 \%$ \\
\hline wywiady, doświadczenia) & $34,1 \%$ & 10 & 10 \\
Materiały związane z rekrutacją & 2 & $24,4 \%$ & $24,4 \%$ \\
\hline Materiały dotyczące bieżącej aktywności uczelni & $5 \%$ & $2,4 \%$ & 1 \\
& 6 & 3 & $2,4 \%$ \\
\hline Razem & $\mathrm{N}=41,65$ & $7,3 \%$ & $12,2 \%$ \\
& $100 \%$ & $\mathrm{~N}=41$ & $\mathrm{~N}=41$ \\
& & & $100 \%$ \\
\hline
\end{tabular}

Przedostatnią kartą serwisu YouTube, którą poddano analizie była karta „Playlisty”, która po prostu stanowi zbiór wszystkich filmów (Tab.6). Z tego rodzaju zawartości kanału YouTube skorzystało 41 uczelni na 48, które posiadały oficjalne konto na YouTubie. Uczelnie te średnio w playlistach posiadały 6,4 katalogi tematyczne. Jeśli chodzi o rodzaj uczelni a liczbę posiadanych katalogów w playlistach to najwięcej po 8,6 katalogów miały uniwersytety i po 8,2 katalogi uczelnie ekonomiczne. Uczelnie techniczne średnio posiadały po 6,7 katalogów. Najmniej bo maksymalnie po 2 katalogi uczelnie wychowania fizycznego.

Tabela 6. Średnia liczba katalogów $w$ playlistach a rodzaj uczelni (opracowanie wtasne)

\begin{tabular}{|l|c|c|}
\hline \multicolumn{1}{|c|}{ Rodzaj uczelni } & $\begin{array}{c}\text { Liczba uczelni } \\
\text { z profilem na YouTube } \\
2017 \text { rok (N) }\end{array}$ & $\begin{array}{c}\text { Średnia liczba } \\
\text { katalogów w playlistach }\end{array}$ \\
\hline Uniwersytety & 16 & 8,625000 \\
\hline Uczelnie techniczne & 15 & 6,733333 \\
\hline Uczelnie ekonomiczne & 4 & 8,250000 \\
\hline Uczelnie pedagogiczne & 4 & 3,250000 \\
\hline Uczelnie rolnicze/przyrodnicze & 5 & 3,250000 \\
\hline Uczelnie wychowania fizycznego & 4 & 2,000000 \\
\hline Uczelnie teologiczne & 0 & 0 \\
\hline Razem & $\mathrm{N}=48$ & 6,437500 \\
\hline
\end{tabular}

Karta „Informacje”, to ostatnia karta YouTuba która została poddana analizie (Tab.7). Jest to miejsce $\mathrm{w}$ serwisie, które po pierwsze pozwala na dodanie opisu kanału, pozwala ustawić kraj kanału, wpisać adres e-mail do kontaktu w sprawach biznesowych, a także podać linki do portali społecznościowych i innych. Kartę „Informacje” uzupełniło jedynie 6 uczelni technicznych, na 15, które posiadały w 2017 roku oficjalny profil na YouTubie. Pozostałe uczelnie 40\% uczelni technicznych (w skali globalnej to aż $-56 \%$ wszystkich uczelni) niestety nie 
skorzystała $\mathrm{z}$ tej możliwości. Uczelnie techniczne, które wykorzystały kartę „Informacje” w pełni, zazwyczaj umieszczały tam krótką notatkę na temat uczelni (odnotowano również przypadki, w których informacja miała zarówno polską jak i angielską wersję) oraz zamieszczały różnego rodzaju linki: do własnej strony internetowej czy innych mediów społecznościowych na których uczelnia posiadała oficjalny profil.

Tabela 7. Zestawienie uczelni technicznych a informacje o uczelni w karcie YouTuba „Informacje” (opracowanie wtasne)

\begin{tabular}{|c|c|c|}
\hline Uczelnia & $\begin{array}{c}\text { Data } \\
\text { założenia } \\
\text { profilu }\end{array}$ & $\begin{array}{c}\text { Czy w karcie } \\
\text { YouTuba } \\
\text { „Informacje” } \\
\text { pojawił się opis } \\
\text { uczelni }\end{array}$ \\
\hline Politechnika Poznańska & 2015 & tak \\
\hline Politechnika Świętokrzyska w Kielcach & 2014 & tak \\
\hline Politechnika Warszawska & 2013 & nie \\
\hline Politechnika Krakowska im. Tadeusza Kościuszki & 2013 & tak \\
\hline Politechnika Łódzka & 2013 & nie \\
\hline Politechnika Rzeszowska im. Ignacego Łukasiewicza & 2013 & nie \\
\hline Politechnika Opolska & 2012 & tak \\
\hline Politechnika Częstochowska & 2011 & nie \\
\hline $\begin{array}{ll}\text { Uniwersytet Technologiczno-Humanistyczny } & \text { im. } \\
\text { Kazimierza Pułaskiego w Radomiu } & \\
\end{array}$ & 2011 & nie \\
\hline $\begin{array}{l}\text { Akademia Techniczno-Humanistyczna w Bielsku - } \\
\text { Białej }\end{array}$ & 2010 & nie \\
\hline Politechnika Gdańska & 2009 & tak \\
\hline Politechnika Śląska (Gliwice) & 2009 & nie \\
\hline $\begin{array}{l}\text { Akademia Górniczo-Hutnicza im. Stanisława Staszica w } \\
\text { Krakowie }\end{array}$ & 2009 & tak \\
\hline Politechnika Wrocławska & 2008 & nie \\
\hline $\begin{array}{l}\text { Zachodniopomorski Uniwersytet Technologiczny w } \\
\text { Szczecinie }\end{array}$ & Brak danych & nie \\
\hline
\end{tabular}

\section{Podsumowanie}

We współczesnej „globalnej wiosce” Marshala McLuhana [7] serwisy społecznościowe stanowią podstawę społecznego istnienia. W nowoczesnych sposobach komunikowania drzemie ogromny potencjał, który coraz bardziej doceniają publiczne jednostki akademickie w Polsce. Pomimo tego, iż Facebook zdominował polskie social media uczelni publicznych (58 na 59 uczelni publicznych w 2017 roku posiadało swój oficjalny profil na Facebooku), serwis YouTube zajmuje drugie miejsce $w$ rankingu platform $\mathrm{z}$ największą liczba użytkowników na świecie.

Analiza oficjalnych profili uczelni technicznych na kanale YouTube wykazała, iż jest to przykład social media, które coraz częściej jest wykorzystywane przez jednostki akademickie jako narzędzie do komunikacji z otoczeniem (aż 15 na 18 uczelni technicznych ma swój oficjalny kanał na YouTubie). Porównując liczbę uczelni korzystających z YouTube w 2012 [8] a liczbę przebadanych globalnych 
profili uczelni wyższych w 2017 roku, przyrost uczelnianych kanałów na YouTubie wzrósł o $166 \%$.

Zdecydowanie materiałami wideo, które można zakwalifikować do kategorii „najpopularniejsze” i są zamieszczane przez uczelnie, nie tylko techniczne, w serwisie YouTube, to materiały związane z promocją bądź szeroko rozumianą reklamą oferty edukacyjnej danej jednostki akademickiej - jest to 55,5\% wszystkich najpopularniejszych filmów na oficjalnym kanale danej uczelni znajdujące się w każdym przypadku na miejscu pierwszym we wszystkich trzech wskazaniach. Zdecydowanie YouTube to social media, które na dzień dzisiejszy stanowi dla uczelni wyższych jeden $\mathrm{z}$ kanałów komunikacyjnych o dużym potencjale. Poczyniona egzemplifikacja aktywności uczelni technicznych na YouTubie ukazuje ile faktycznie politechnik korzysta z tego medium i w jaki sposób wykorzystuje techniczne możliwości YouTube. Zaprezentowaną analizą można potraktować jako implikację do dalszych eksploracji naukowych na ten temat.

\section{LITERATURA}

1. Serwis internetowy DataReportal, Digital 2020: October Global Statshot: https://datareportal.com/reports/digital-2020-october-global-statshot

2. KOSMALSKA B.: Telewizja a globalizacja kultury [w:] Media i społeczeństwo: nowe strategie komunikacyjne, red. Sokołowski M., Wydawnictwo Adam Marszałek, Toruń 2008.

3. MARCHWICKI M.: YouTube w liczbach. Ponad $20 \mathrm{mln}$ użytkowników w Polsce. Social Press 2015, https://socialpress.pl/2015/02/youtube-ma-10-latzobacz-jak-zmienial-sie-w-tym-czasiel, 7.12.2017.

4. LEVINSON P.: Nowe nowe media. Wydawnictwo WAM, Kraków 2010.

5. Serwis internetowy Portalmedialny.pl. YouTube w liczbach. Ponad $20 \mathrm{mln}$ użytkowników w Polsce, 2017: http://www.portalmedialny.pl/art/58400/youtubew-liczbach-ponad-20-mln-uzytkownikow-w-polsce.html

6. Serwis internetowy Portalmedialny.pl. Marek Molicki o YouTube: YouTube rynek wideo $w$ sieci zdefiniował i wyznaczył trendy: http://www.portalmedialny.pl/art/58381/marek-molicki-o-youtube-youtuberynek-wideo-w-sieci-zdefiniowa-i-wyznaczy-trendy.html

7. McLUHAN M.: Galaktyka Gutenberga: tworzenie człowieka druku. Narodowe Centrum Kultury, Warszawa 2017.

8. KULCZYCKI E.: Wykorzystanie mediów społecznościowych przez akademickie uczelnie wyższe w Polsce. Badanie w formule otwartego notatnika. Uniwersytet im. Adama Mickiewicza w Poznaniu, 2012. 